\title{
Allergenic potency of kiwi fruit during fruit development
}

\author{
Marija Gavrovic-Jankulovic, Natalija Polovic, Sladjana Prisic , Ratko M. \\ Jankov, Marina Atanaskovic-Markovic, Olga Vuckovic \& Tanja Cirkovic \\ Velickovic
}

To cite this article: Marija Gavrovic-Jankulovic , Natalija Polovic , Sladjana Prisic, Ratko M. Jankov , Marina Atanaskovic-Markovic , Olga Vuckovic \& Tanja Cirkovic Velickovic (2005) Allergenic potency of kiwi fruit during fruit development, Food and Agricultural Immunology, 16:2, 117-128, DOI: $10.1080 / 09540100500090804$

To link to this article: https://doi.org/10.1080/09540100500090804

册Published online: 19 Jan 2007.

Submit your article to this journal $₫$

Lll Article views: 457

Q View related articles ¿

Citing articles: 24 View citing articles ๘ 


\title{
Allergenic potency of kiwi fruit during fruit development
}

\author{
MARIJA GAVROVIC-JANKULOVIC ${ }^{1}$, NATALIJA POLOVIC ${ }^{1}$, \\ SLADJANA PRISIC ${ }^{1 \star}$, RATKO M. JANKOV ${ }^{1}$, MARINA \\ ATANASKOVIC-MARKOVIC ${ }^{2}$, OLGA VUCKOVIC ${ }^{3}, \&$ TANJA \\ CIRKOVIC VELICKOVIC ${ }^{1}$
}

${ }^{1}$ Faculty of Chemistry, Department of Biochemistry, University of Belgrade, Belgrade, Serbia,
${ }^{2}$ University Children's Hospital, Department of Allergology and Pulmonology, Belgrade, Serbia,
and ${ }^{3}$ Institute for Immunology and Virology “Torlak”, Department of Allergy, Belgrade, Serbia (Received 29 April 2004; accepted 7 February 2005)

\begin{abstract}
Food allergies, including kiwi fruit allergy, have been the subject of extensive research in the last few years. The aim of this study was to examine a possible relationship between the developmental stage of kiwi fruit and its allergenic potency. The protein and allergen patterns of kiwi fruit extracts in September, October, November and December fruit in the period from 2000-2002 were analysed. One of the factors that may contribute to the difficulties in proposing well-defined and standardized fruit extracts should also be the time of fruit harvesting. In this particular case, when the kiwi fruit was edible throughout November and December, we showed discrepancies in allergen content and potencies both in qualitative and quantitative terms. Two major allergens of kiwi fruit, Act c 1 and Act c 2, mainly accounted for the highest allergenic potential of November kiwi extract in vivo and in vitro. Not only the content of major allergens, but also the ratio of different proteins and even isoforms of the same allergen (Act c 2) change with fruit ripening. These findings should be taken into account during preparation of extracts for allergy diagnosis.
\end{abstract}

Keywords: Kiwi fruit, Actinidia deliciosa, food allergy, allergen, actinidin, thaumatin-like protein, development, ripening.

Abbreviations: Oral-allergy syndrome (OAS), skin prick testing (SPT), sodium dodecylsulfate-polyacrylamide gel electrophoresis (SDS-PAGE), bovine serum albumine (BSA), Tris-buffered saline (TBS), phosphate-buffered saline (PBS), thaumatin-like protein (TLP), polyvinylpoly-pyrrolidone (PVPP), Coomassie Brilliant Blue (CBB), simulated gastric fluid (SGF), Rocket immunoelectrophoresis (RIE).

\footnotetext{
${ }^{\star}$ Currently at Iowa State University, Ames, Iowa, USA

Correspondence: Tanja Cirkovic Velickovic, Faculty of Chemistry, Department of Biochemistry, University of Belgrade, Studentski trg 16, Belgrade, Serbia. Tel: 381113282 630. Fax: 38111638 785. E-mail: tcirkov@chem.bg.ac.yu
} 


\section{Introduction}

Food allergy is an important health problem nowadays. Clinical reactions to food, including cutaneous, gastrointestinal or respiratory disorders or systemic anaphylactic reactions (Sampson 1999) are demonstrated by $8 \%$ of children and $2 \%$ of adults (Helm \& Burks 2000). It is likely that both the incidence and prevalence of food allergies are increasing in line with other forms of allergic diseases (Kimber \& Dearman 2001). Food allergy can develop as an isolated reaction to food (fruit, fish, milk) or a secondary reaction after sensitization to pollen (oral-allergy syndrome, OAS) or latex (latex-fruit syndrome) when food allergens cross-react with allergens present in pollen or latex. It is generally believed that food allergens are proteins resistant to digestion because only intact proteins (or their larger fragments) are required for processing by antigen-presenting cells located in gut mucosa. Although stability under digestion may not be the defining characteristic of food allergens, it is widely accepted that resistance to digestion would increase the probability of stimulating allergic reactions presumably by retaining protein integrity ( $\mathrm{Fu} \mathrm{2002)}$. Thus, digestibility tests have been widely accepted as an appropriate method for evaluating the potential allergenicity of newly-introduced proteins in genetically modified plants (Metcalfe et al. 1996, Fu et al. 2002).

Kiwi fruit is very popular throughout the world because of its taste and high vitamin $\mathrm{C}$ content. The kiwi fruit harvest season is in late autumn in the Mediterranean area. September and October fruits are not edible because they are hard, sour and lacking aroma. The fruit is fully ripened in November and December.

Accompanying the growing popularity of kiwi fruit in the regular diet, there has been an increasing number of reports of adverse and allergic reactions to kiwi (Garcia et al. 1989, Pastorello et al. 1996, Pastorello et al. 1998, Rudescho et al. 1998, Gavrovic-Jankulovic et al. 2002b, Bublin et al. 2004), which is often pollen associated. According to earlier studies, at least 12 IgE binding proteins (allergens) could be detected in kiwi extract with molecular weights ranging from $64-12 \mathrm{kDa}$ (Pastorello et al. 1996). Two major allergens of kiwi fruit have been isolated and characterized. Act $\mathrm{c}$ 1 , a protein of molecular mass about $30 \mathrm{kDa}$, commonly known as actinidin (Pastorello et al. 1998) is a cysteine protease related to papain (Varughese et al. 1992). Act c 2 is a thaumatin-like protein, the plant defense protein with proven antifungal activity (Gavrovic-Jankulovic et al. 2002b, Wang et al. 2002) that, in kiwi extract, exists in two isoforms differing slightly in pI value (9.4 and 9.5) with molecular mass of about $24 \mathrm{kDa}$ (Gavrovic-Jankulovic et al. 2002b).

Allergenicity of fruit during development depends on the expression of IgE-binding proteins. Vieths et al. (1994) demonstrated that the severity of symptoms in patients allergic to apples was highly correlated with the appearance of $18 \mathrm{kDa}$ apple allergen during storage and suggested that this was caused by ripening. Additionally, Paschke et al. (2001) have correlated the number and intensity of bands in immunoblots with ripening stages of mango fruit and observed no difference caused by ripening.

Allergenic extracts, made by different manufacturers, for the use in diagnosis and therapy of allergic diseases usually show variations in allergenic potency. Especially allergen extracts from fruits, vegetables and other plant foods often lack sufficient biological activity due to the presence of proteolytic enzymes, carbohydrates, and phenol components (Vieths et al. 2001). That is the consequence of applying different extraction methods and source materials. In the last few years several in vivo (such as skin prick testing, food challenge, etc.) and in vitro (measurement of the content of the 
major allergen) methods for standardization of allergenic extracts have been proposed (Yunginger 1991, Esch 1997, Duffort et al. 2002).

The purpose of this study was to examine a possible relationship between the developmental stage (from September to December) of kiwi fruit and its allergenic potency. We monitored the protein and allergen content during development, digestibility of allergen samples in simulated gastric fluid and allergenic potential in vivo by skin prick testing (SPT). In the purpose of standardization, we correlated three different methods for the quantification of the major allergen Act c 1 .

\section{Materials and methods}

\section{Fruit collection and protein extract preparation}

Kiwi fruits (Actinidia deliciosa, Monti cultivar) were collected monthly from September to December in the period from 2000 to 2002, from the same tree in Bar, Montenegro. The fruits were stored at $-20^{\circ} \mathrm{C}$ without specific treatment until use. The extracts were made according to previously published protocol (GavrovicJankulovic et al. 2002b). Briefly, the fruits were homogenized 1:2(w/v) in $100 \mathrm{mM}$ sodium bicarbonate buffer, $\mathrm{pH} 9.3$ containing $2 \%$ polyvinylpoly-pyrrolidone (PVPP) and $0.02 \% \mathrm{NaN}_{3}$ in a blender for $1 \mathrm{~min}$. After extraction and centrifugation, ammonium sulfate was dissolved in the supernatants to achieve $90 \%$ saturation. After overnight standing at $4{ }^{\circ} \mathrm{C}$ the solutions were centrifuged for $20 \mathrm{~min}$ at $10000 \times \mathrm{g}$. The obtained pellets were dissolved in a minimal volume of a starting buffer and dialyzed extensively against the same buffer. Protein concentration in the extract was determined by the Bradford assay (Bradford 1976).

Sodium dodecylsulfate-polyacrylamide gel electrophoresis (SDS-PAGE). SDS-PAGE was performed on $4 \%$ stacking gel and $10 \%$ or $12 \%$ resolving gel according to the method of Laemmli (Laemmli 1970) under reducing and non-reducing conditions. Twelve micrograms of proteins per lane were applied on the gel for Coomassie Brilliant Blue (CBB) staining or semidry transfer $\left(0.8 \mathrm{mAcm}^{-2}\right)$ to a nitrocellulose membrane (Serva) for further examination. The content of major allergen Act c 1 in kiwi fruit extracts was determined by densitometric analysis after SDS-PAGE under reducing conditions.

Two-dimensional polyacrylamide gel electrophoresis. Two-dimensional PAGE isoelectric focusing was performed in a model 2117 Multiphor cell (LKB Pharmacia), according to the manufacturer's instructions. The proteins (35 $\mu \mathrm{g}$ per lane) were applied to isoelectric focusing gel and further separated by SDS-PAGE under the conditions previously described (Gavrovic-Jankulovic et al. 2000).

Immunoblotting. The separated proteins on the gel were transferred onto a nitrocellulose membrane, as described by Towbin et al. (1979). The quality of the transfer was checked by staining the nitrocellulose with $0.1 \%$ Ponceau $S$ in $5 \%$ acetic acid. The nitrocellulose membranes were blocked with $1 \%$ bovine serum albumine (BSA) in Tris-buffered saline (TBS) containing $0.05 \%$ Tween 20, pH 7.8 for 1 hour at room temperature. After blocking, the membranes were incubated with the allergic patients' serum diluted $1: 5$ in $0.1 \%$ BSA in TBS containing $0.05 \%$ Tween 20, $\mathrm{pH} 7.8$ for 5 hours. The blots were washed extensively with TBS containing $0.05 \%$ 
Tween 20, $\mathrm{pH} 7.8$ and incubated for $2 \mathrm{~h}$ with 1: 1000 diluted monoclonal anti-human IgE antibody labeled with alkaline phosphatase (Abcam Ltd., Cambridge Science Park) and, after washing, were visualized using nitro blue tetrazolium and 5-bromo4-chloro-3-indolyl phosphate (Sigma Chemical Co., St Louis, MO, USA) as substrates as described (Gavrovic-Jankulovic et al. 2002a). A serum pool of nonallergic persons was used as the negative control.

Digestion with simulated gastric fluid. The digestibility of kiwi proteins in simulated gastric fluid (SGF) was examined according to the method of Yagami et al. (2000). Briefly, $140 \mu \mathrm{g}$ of kiwi extract proteins was dissolved in $40 \mu \mathrm{L}$ of prewarmed SGF (US Pharmacopoeia) containing $0.32 \% \mathrm{w} / \mathrm{v}$ of pepsin A (Sigma Chemical Co.). Digestion proceeded at $37^{\circ} \mathrm{C}$ with continuous shaking and an aliquot $(8 \mu \mathrm{L})$ of the digest was periodically withdrawn (at 8 and 30 minutes). The digestion was stopped with $2.4 \mu \mathrm{L}$ $0.2 \mathrm{M} \mathrm{Na}_{2} \mathrm{CO}_{3}$, and samples were mixed with a sample buffer for SDS-PAGE analysis.

Determination of proteolytic activity of actinidin. Proteolytic activity of actinidin in different kiwi fruit samples towards $0.5 \mathrm{mM} \mathrm{N} \alpha$-Benzoyl-DL-Arginine 4-nitroanilide (Sigma) in $0.1 \mathrm{M}$ potassium phosphate buffer, $\mathrm{pH}$ 6.5, containing $1 \mathrm{mM}$ EDTA, 13 $\mathrm{mM}$ L-cysteine and $5 \mathrm{mM}$ dithiothreitol at RT was evaluated by spectral analysis at $410 \mathrm{~nm}$. Specific proteolytic activity was calculated using excintion coefficient of 4nitroaniline and protein concentrations data. Relative proteolytic activity was calculated as percent of November extract proteolytic activity (set up as $100 \%$ ). Effects of the fruit extract pigments were minimized by preparing probes for each sample without addition of the substrate. Absorbance was read after $1 \mathrm{~h}$ of incubation.

A zymogram was run according to Grobe et al. (2002) with some modifications. Briefly, $12 \mu \mathrm{g}$ of November kiwi extract proteins previously resolved by isoelectrofocusing were applied to $12 \%$ resolving gel copolymerized with $0.1 \%$ gelatin for 2D-PAGE analysis. After electrophoresis, the gel was incubated in a buffer containing

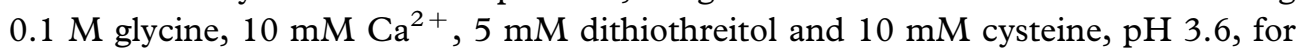
$16 \mathrm{~h}$, followed by staining with CBB.

Antisera production. Antibodies against the December kiwi extract were raised in rabbits according to Harboe and Ingild (1983). The animals were injected with $0.5 \mathrm{~mL}$ of a $1: 1$ emulsion of ripe kiwi extract $\left(1 \mathrm{mgmL}^{-1}\right)$ in complete Freund's adjuvant. Bleeding was performed 50 days after the first immunization and every two weeks thereafter. The presence of antibodies to kiwi proteins was detected by immunodiffusion. The serum was partially purified by ammonium sulfate fractionation (50\% saturation).

Rocket immunoelectrophoresis (RIE). The kiwi extract proteins $(5.5 \mu \mathrm{g})$ were applied to $1 \%$ agarose gel containing $13 \%$ rabbit antibodies on a glass plate $(12 \times 7 \mathrm{~cm})$. Electrophoresis was carried out in a buffer containing $5 \mathrm{mM}$ barbital, $25 \mathrm{mM} \mathrm{Na}-$ barbital, $\mathrm{pH} 8.6$, for $12 \mathrm{~h}$ at $2 \mathrm{~V} \mathrm{~cm}^{-1}$. In order to compare the amount of the major allergen Act c 1 in different kiwi fruit samples, we applied $2.75 \mu \mathrm{g}$ Act c 1 isolated according to Carne and Moore (1978) without derivatization with S-sulphenyl thiosulphate on the same agarose gel. 
Patient sera. Five sera from patients allergic to kiwi fruit were used in this study $(1,2$, 3, 4 and 5). All the patients showed OAS and one of them had severe contact dermatitis and anaphylaxis when touching the fruit (case No. 4 in Table I).

Skin tests. The extracts for skin prick testing (SPT) were prepared in phosphatebuffered saline (PBS) (10 mM phosphate buffer, 0.9\% NaCl, $\mathrm{pH} 7.2) 1: 1(\mathrm{w} / \mathrm{v})$, centrifuged for $5 \mathrm{~min}$ at $10000 \times \mathrm{g}$, filtered and neutralized with $\mathrm{NaHCO}_{3}$ yielding a final protein concentration of $0.07 \mathrm{mgmL}^{-1}$. SPT as performed on the volar surface of the forearm with the kiwi extracts prepared as previously described (Malling 1993). Histamine $\left(0.010 \mathrm{mgL}^{-1}\right)$ was used as the positive control and saline $(0.9 \%)$ as the negative control. The results of SPT were read after $20 \mathrm{~min}$. Wheal diameters were expressed relative to the histamine response.

\section{Results}

\section{Kiwi fruit extracts}

Kiwi fruit extracts (gathered in 2000, 2001 and 2002) were compared using SDSPAGE, immunoblot and rocket immunoelectrophoresis. The same protein/antigen/ allergen patterns were observed in all three years investigated. The concentration of proteins in kiwi fruit extracts increased with fruit development. The results presented here were all obtained using samples from the year 2001 .

Protein patterns and actinidin activity in the zymogram. At least 10 protein bands with molecular weights between 67 and $10 \mathrm{kDa}$ were detected by CBB staining in extracts of kiwi fruit from September to December. SDS-PAGE patterns under reducing (see Figure 1a) and non-reducing (Figure 1b) conditions were quite different. The most noticeable difference was in the mobility of the 24 and $30 \mathrm{kDa}$ proteins in reducing conditions (most likely a thaumatin like protein and actinidin, respectively) compared to non-reducing conditions, when they exhibited 20 and $27 \mathrm{kDa}$ molecular weights, respectively. The protein of $29 \mathrm{kDa}$ was constitutively expressed. We also noticed three protein bands of 10, 12 and $14 \mathrm{kDa}$ with similar appearance and in similar amounts from September to December. Several more protein bands of about 42, 56 and 62 $\mathrm{kDa}$ were also present in the extracts of fruits from September to December. Protein bands of 17, 22 and $39 \mathrm{kDa}$ appeared in September and reached the highest intensity

Table I. Clinical data and skin test results of five patients allergic to kiwi.

\begin{tabular}{llcccc}
\hline $\begin{array}{l}\text { Patient } \\
\text { no. }\end{array}$ & Diagnosis & $\begin{array}{c}\text { Kiwi: September } \\
\text { SPT }\end{array}$ & $\begin{array}{c}\text { Kiwi: October } \\
\text { SPT }\end{array}$ & $\begin{array}{c}\text { Kiwi: November } \\
\text { SPT }\end{array}$ & $\begin{array}{c}\text { Kiwi: December } \\
\text { SPT }\end{array}$ \\
\hline 1 & RC/ OAS & + & + & ++ & + \\
2 & BA/ OAS & +++ & +++ & +++++ & +++ \\
3 & RC/OAS & +++ & +++ & ++++ & +++ \\
4 & CD/A & ++ & ++ & +++++ & ++++ \\
5 & RC/AE & +++ & +++ & +++++ & +++ \\
\hline
\end{tabular}

OAS, oral-allergy syndrome; RC, rhinoconjunctivitis; BA, bronchial asthma; AE, angioedema; A, systemic anaphylaxis; CD, contact dermatitis. The protein concentration in the extracts for the experiment of SPT has adjusted to $0.07 \mathrm{mgmL}^{-1}$. 
(a)

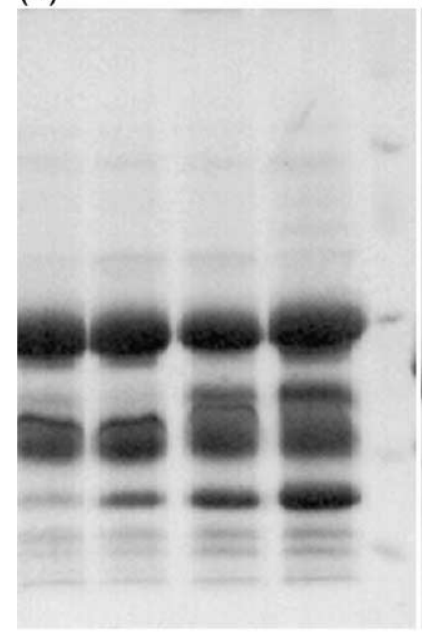

(b)

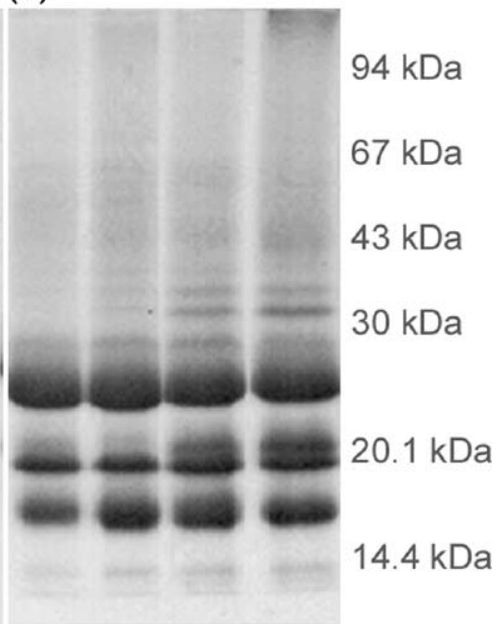

\section{$\begin{array}{lllllllllllllllll}S & O & N & D & m & S & O & N & D\end{array}$}

Figure 1. SDS PAGE of kiwi fruit extracts.

Lane m, Molecular weight markers; S, September; O, October; N, November and D, December kiwi fruit extract; a) separation in reducing conditions; b) separation in non-reducing conditions.

in December. Other protein bands of 26 and $67 \mathrm{kDa}$ appeared in September and became most abundant in November.

Two-dimensional PAGE (Figure 2) showed fragmentation of the $30 \mathrm{kDa}$ protein (actinidin), pI 3.6 into a $26 \mathrm{kDa}$ protein with a pI value of 3.2. Both the protein and

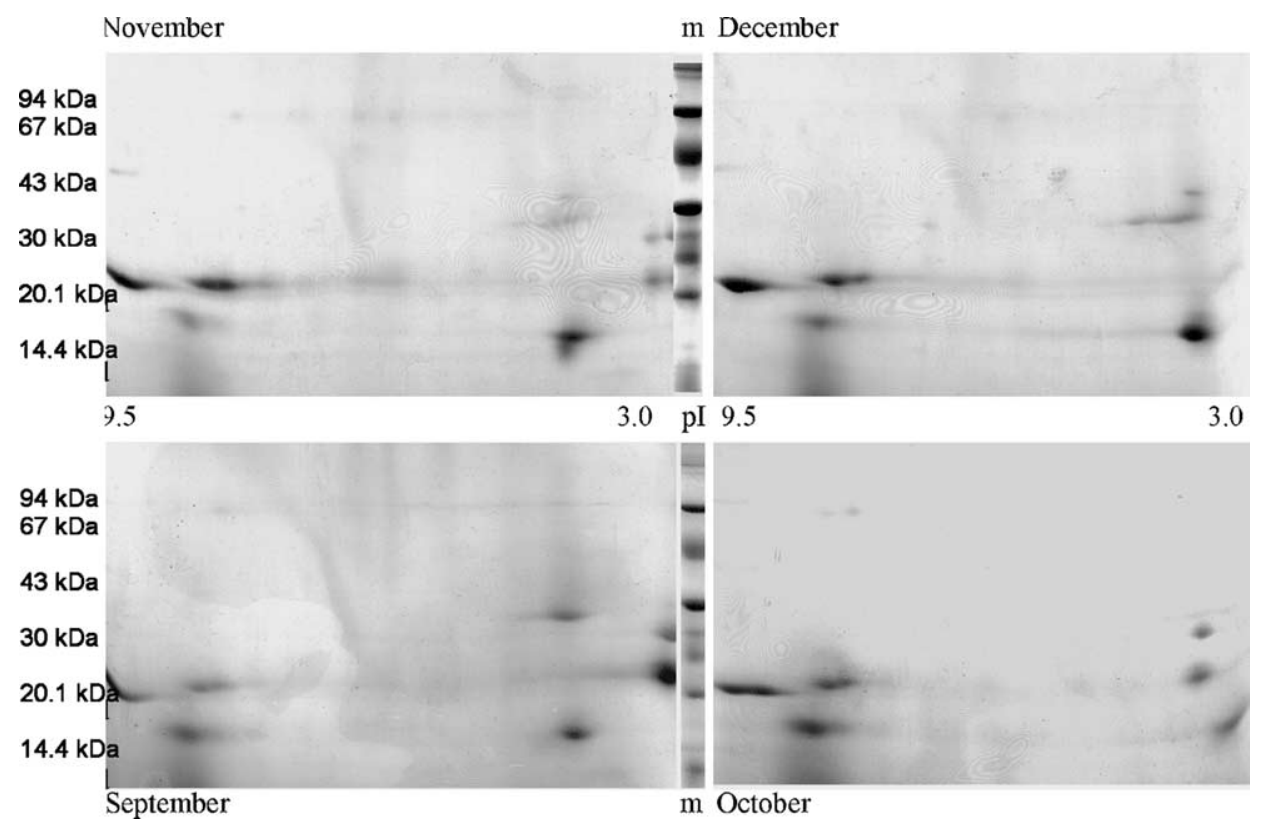

Figure 2. Two-dimensional PAGE of kiwi fruit extracts.

Lane $\mathrm{m}$, Molecular weight markers 
protein fragment showed proteolytic activity in zymogram (Figure 3). We observed two more proteins of 39 and $17 \mathrm{kDa}$ with pI values of 5.0 and 4.8 , respectively.

The major kiwi fruit allergen Act c 2 was present in all extracts as a mixture of isoforms with isoelectric points of 9.4 and 9.5 and a molecular weight of $24 \mathrm{kDa}$ (Gavrovic-Jankulovic et al. 2002b). Its content increased with fruit development. The amount of the $26 \mathrm{kDa}$ protein, pI 8.8, was the highest in the November extract. Also, a protein of $17 \mathrm{kDa}$ with $\mathrm{pI} 9.0$ reached the highest band intensity in the December kiwi fruit extract.

Human IgE binding. In immunoblots developed with individual sera $(1,2,3,4)$ or pool of the patients sera $(1,2,3$, and 4 ) (see Figure $4 a$ ) a significant number of IgE binding proteins were detected. The most intensive bands found in all four extracts, were 30 and $24 \mathrm{kDa}$ proteins (corresponding to actinidin and thaumatin-like protein). An allergen of $29 \mathrm{kDa}$ was also present in all extracts. Other allergens clearly showed a dependence on the developmental stage. IgE-binding proteins of 17, 26, 39, 42, 56 and $62 \mathrm{kDa}$ were more abundant in later months. Allergens of 42 and $68 \mathrm{kDa}$ were present in the October and November samples. The allergen of $22 \mathrm{kDa}$ was most pronounced in the November sample.

Another immunoblot developed after incubation with serum from patient No. 5 (Figure 4b), showed no difference between the extracts of kiwi fruits in different stages of development. Each strip had only one band corresponding to a $24 \mathrm{kDa}$ protein. However, according to the SPT results (case No. 5 in Table I), a quantitative difference between the extracts tested for the same patient did exist. An explanation for the phenomenon that in vivo testing appeared much more sensitive than in vitro

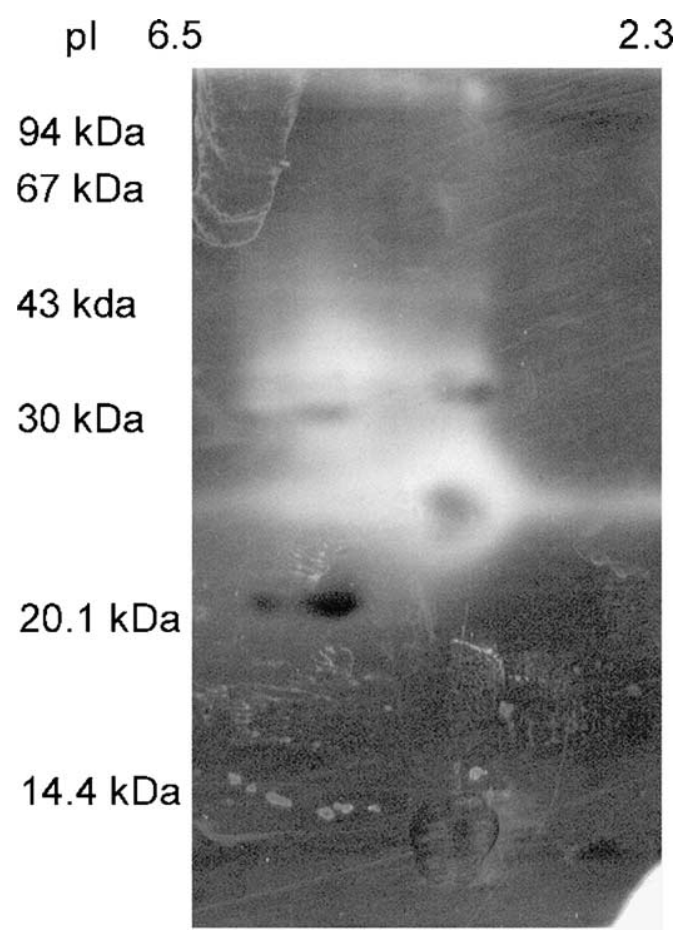

Figure 3. Proteolytic activity of actinidin fragments from the November kiwi fruit extract after 2D PAGE. 


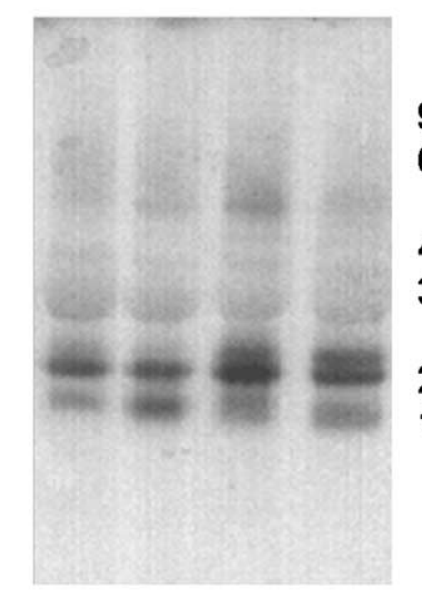

a) $\mathrm{S} \quad \mathrm{O} \quad \mathrm{N} \quad \mathrm{D}$

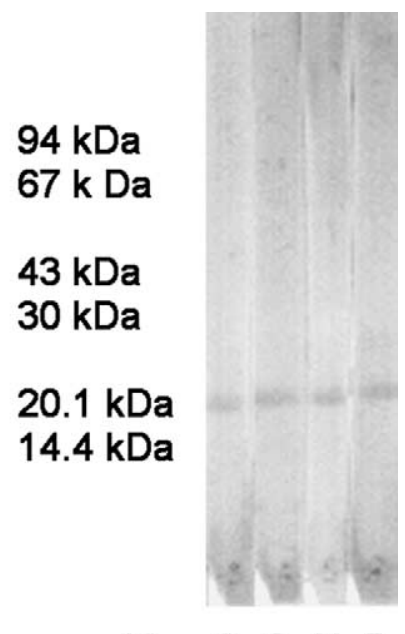

b) $S O \mathrm{ND}$

Figure 4. Binding patterns of patients' IgE to kiwi fruit extracts after Western blotting. a) immunoblot with serum pool; b) immunoblot with serum from patient 2 .

S, September; O, October; N, November and D, December kiwi fruit extract.

techniques, could be that not all of the mainly conformational IgE-binding epitopes have been renaturated after transfer to the NC membrane for immunoblot analysis, as demonstrated for some other allergens of different sources (Nilsen et al. 1991).

Quantification of actinidin. The quantity of actinidin in our samples (see Table II) was measured using three different methods: rocket immunoelectrophoresis, densitometry and determination of proteolytic activity. Rocket immunoelectrophoresis was run according to Hudson and Hay (1989). According to all three methods used in this study, the quantity of Act c 1 was the most pronounced in November kiwi fruit extract (Table II). The most noticeable difference in Act c 1 content between the November kiwi fruit extract and the other three kiwi fruit extract was obtained by determination of proteolytic activity.

Digestibility of kiwi proteins. All kiwi proteins in September, October, November and December kiwi fruit extracts were decomposed completely within 30 minutes of exposure to simulated gastric fluid (see Figure 5), but the $24 \mathrm{kDa}$ protein (presumably

Table II. Quantity of major allergen Act c 1 determined by three different methods.

\begin{tabular}{lcccccccc}
\hline & \multicolumn{7}{c}{ Kiwi fruit sample } \\
\cline { 2 - 9 } Method used & $\mathrm{S}^{\#}$ & $\mathrm{~S}^{\star}$ & $\mathrm{O}^{\#}$ & $\mathrm{O}^{\star}$ & $\mathrm{N}^{\#}$ & $\mathrm{~N}^{\star}$ & $\mathrm{D}^{\#}$ & $\mathrm{D}^{\star}$ \\
\hline RIE & 43.6 & 81.3 & 43.6 & 81.3 & 53.6 & 100 & 43.6 & 81.3 \\
Densitometry & 36.9 & 93.9 & 37.6 & 95.7 & 39.3 & 100 & 35.7 & 90.8 \\
Relative proteolytic activity of Act c $1^{\Delta}$ & & 51.1 & & 65.7 & & 100 & & 70.6 \\
\hline
\end{tabular}

S, September; O, October; N, November; D, December; RIE, Rocket immunoelectrophoresis; ${ }^{*} \%$ of total protein quantity; $\star \%$ of November actinidin quantity; $\Delta_{\%}$ of November actinidin activity. 


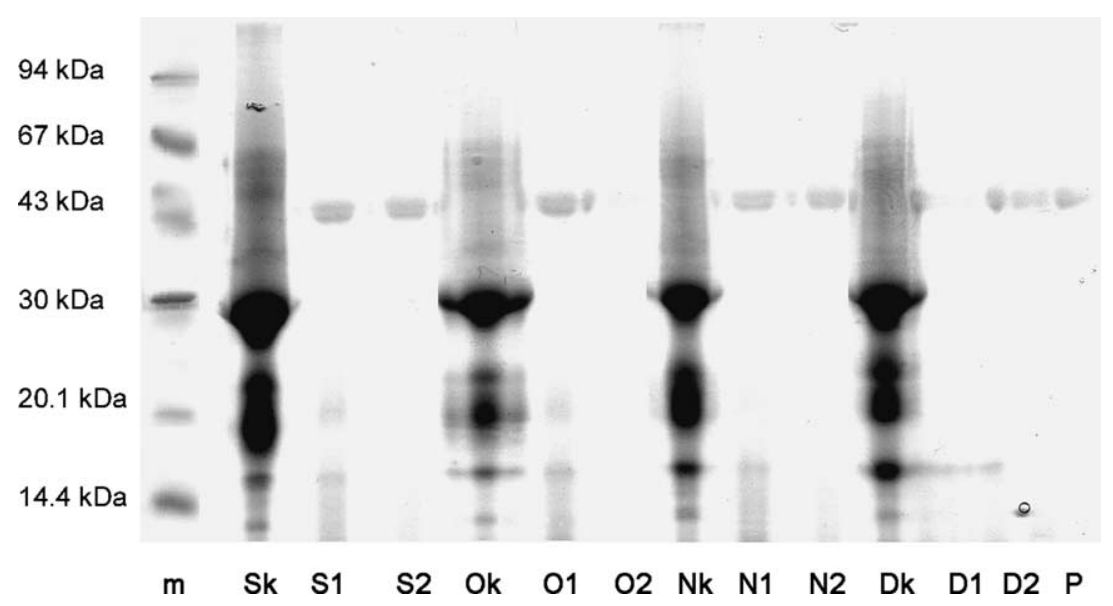

Figure 5. Digestibility of kiwi fruit extracts in SGF.

Lane m, Molecular weight markers; S, September; O, October; N, November and D, December kiwi fruit extract; k, extract control; 1, after 8 min of digestion; 2, after $30 \mathrm{~min}$ of digestion; Lane P, pepsin control.

a thaumatin-like protein (TLP), Act c 2) appeared to be more resistant to digestion by gut enzymes in unripe fruit extracts.

Skin prick testing. The results of SPT and patients' clinical characteristics are shown in Table I. All patients exhibited the most pronounced reaction to the November kiwi fruit extract. The intensity of the reaction to November kiwi fruit extract was approximately twice as strong as the response to the other kiwi fruit extracts (September, October and December).

\section{Discussion}

The aim of this study was to correlate the allergen profile and content in kiwi fruit during ripening and to answer the question whether the allergenicity and the digestibility of the fruit depend on its developmental stage or not.

We analysed kiwi fruit extracts from three consecutive years (2000, 2001 and 2002) by SDS-PAGE, 2D-PAGE, immunoblot and rocket immunoelectrophoresis. These extracts exhibited the same allergen and protein profile, ruling out the possibility that our results may depend on specific conditions of the year selected.

The allergenic potential in vivo of the different developmental stages of kiwi fruit (September, October, November and December extracts) investigated by skin prick tests was the highest in extract of fruit collected in November. The amount of Act c 1 (actinidin) was the highest in the same sample. The content of this major allergen of kiwi fruit was measured by rocket immunoelectrophoresis, densitometry and proteolytic activity. Proteolytic activity increased in September to November kiwi fruit extracts and decreased in the December extract, while the actinidin contents determined by densitometry and RIE for September, October and December samples were comparable. These results led us to conclude that actinidin might not be fully active in unripe kiwi fruit and that the amount and activity decreased with overripening. According to our results, determination of proteolytic activity cannot be an appropriate method for quantification of actinidin in different kiwi fruit samples. 
Moreover, the difference in the content of Act c 1 (measured by RIE and densitometry) was not sufficiently pronounced to fully explain the extent of patients' reactions. It seems likely that other allergens, whose content also changes during development, contribute to the intensity of skin reactions. In the December extract the intensity of a more basic isoform of Act c 2 on 2D PAGE was higher when compared to the September, October and November extracts. Interestingly, it seems that this isoform, with a presumably higher allergenic potential, appeared to be more prone to digestion in simulated gastric conditions (see Figure 5). Additionally, we noticed that the expression of some until now uncharacterized allergens, started in September and intensified to reach the highest value in November and December $(17,22,26,39$ and $67 \mathrm{kDa}$ molecular weights). These allergens may also contribute to higher allergenicity of the November extract. Also, it would be of interest to examine the role that these proteins may play in the process of kiwi fruit development.

A previous study by Paschke et al. (2001) showed no difference between allergenic potency of mango fruit during ripening but cannot be directly compared with our results due to the different time-scale of food collection (different fruit developmental stage samples). Kiwi fruits used in our study were harvested in September and October as unripe, while November and December kiwi fruits were ripe and edible. The fruit extracts were made immediately after harvesting. Paschke et al. (2001) performed their experiments only on extracts of consumable and fully developed mango fruit made five to 40 days after harvesting.

According to our results, one of the factors that contribute to the difficulties in proposing well-defined and standardized fruit extracts should also be time (developmental stage) of fruit harvesting. In this particular case, when the kiwi fruit was edible throughout November and December, we clearly showed strong discrepancies in allergen content and potencies both in qualitative and quantitative terms. It seems that in the case of kiwi fruit, the fully ripened fruit contains less allergens and was able to induce less pronounced allergic reaction in the SPT in the group of tested patients. However, when considering the allergen extract preparation, it should be kept in mind that not only the content of major allergens, but also the ratio of different proteins and even isoforms of the same allergen change with fruit ripening and development. For an optimized extract preparation, a well defined harvesting time should be taken into account. For the improvement of in vitro allergy diagnosis preparations based on optimized allergen extracts as well as recombinant allergens of natural fruit allergens (Vieths et al. 2001) may be a promising solution for this very complex problem.

\section{Acknowledgement}

This research was supported in part by grant No. 1802 from the Serbian Government, Ministry of Science, Technologies and Development.

\section{References}

Bradford MM. 1976. A rapid and sensitive method for the quantification of microgram quantities of protein utilizing the principle of protein-dye binding. Analytical Biochemistry 72:248-254.

Bublin M, Mari A, Ebner C, Knulst A, Scheiner O, Hoffmann-Sommergruber K, Breiteneder H, Radauer C. 2004. IgE sensitization profiles toward green and gold kiwifruits differ among patients allergic to kiwifruit from 3 European countries. Journal of Allergy and Clinical Immunology 114:1169-1175.

Carne A., Moore C. 1978. The amino acid sequence of the tryptic peptides from actinidin, a proteolytic enzyme from the fruit of Actinidia chinesis. Biochemical Journal 173:73-83. 
Duffort OA, Polo F, Lombardero M, Diaz-Perales A, Sanchez-Monge R, Garcia-Casado G, Salcedo G, Barber D. 2002. Immunoassay to quantify the major peach allergen Pru p 3 in foodstuffs. Differential allergen release and stability under physiological conditions. Journal of Agricultural and Food Chemistry 50:7738-7741.

Esch RE. 1997. Allergen source materials and quality control of allergenic extracts. Methods: A Companion to Methods in Enzymology 13:2-13.

Fu T-J. 2002. Digestion stability as a criterion for protein allergenicity assessment. Annals of the New York Academy of Sciences 964:99-110.

Fu T-J, Abbott UR, Hatzos C. 2002. Digestibility of food allergens and nonallergenic proteins in simulated gastric fluid and simulated intestinal fluid-a comparative study. Journal of Agricultural and Food Chemistry 50:7154-7160.

Garcia BE, De La Cuesta CG, Santos F, Feliu X, Cordoba H. 1989. A rare case of food allergy: monosensitivity to kiwi (Actinidia chinesis). Allergologia et Immunopathologia (Madrid) 17:217-218.

Gavrovic-Jankulovic M, Cirkovic T, Bukilica M, Fahlbusch B, Petrovic S, Jankov RM. 2000. Isolation and partial characterization of Fes p 4 allergen. Journal of Investigational Allergology and Clinical Immunology 10:361-367.

Gavrovic-Jankulovic M, Cirkovic T, Burazer L, Vuckovic O, Jankov RM. 2002a. IgE cross-reactivity between Meadow Fescue pollen and kiwi fruit in patients' sera with sensitivity to both extracts. Journal of Investigational Allergology and Clinical Immunology 12:279-286.

Gavrovic-Jankulovic M, Cirkovic T, Vuckovic O, Atanaskovic-Markovic M, Petersen A, Gojgic G, Burazer L, Jankov RM. 2002b. Isolation and biochemical characterization of a thaumatin-like kiwi allergen. Journal of Allergy and Clinical Immunology 110:805-810.

Grobe K, Poppelmann M, Becker WM, Petersen A. 2002. Properties of group I allergens from grass pollen and their relation to cathepsin B, a member of the $\mathrm{C} 1$ family of cysteine proteinases. European Journal of Biochemistry 269:2083-2092.

Harboe N, Ingild A. 1983. Immunization, isolation of immunoglobulins, estimation of antibody titer. Scandinavian Journal of Immunology 17:345-351.

Helm R, Burks W. 2000. Mechanisms of food allergy. Current Opinion in Immunology 12:647-653.

Hudson L, Hay F. 1989. Antibody interaction with Antigen, in Practical Immunology. 3rd ed. Oxford, UK: Blackwell Scientific Publication. p 242-244.

Kimber I, Dearman R. 2001. Food allergy: What are the issues? Toxicology Letters 120:165-170.

Laemmli UK. 1970. Cleavage of structural proteins during the assembly of the head of bacteriophage T4. Nature 227:680-685.

Malling HJ. 1993. Methods of skin testing. In: Dreborg S, Frew A, editors. Allergen standardization and skin tests. Allergy 48(suppl):55-56.

Metcalfe DD, Astwood JD, Townsend R, Sampson HA, Taylor SL, Fuchs RL. 1996. Assessment of the allergenic potential of foods derived from genetically engineered crop plants. Critical Reviews in Food Science and Nutrition 36(Suppl.):S165-S186.

Nilsen BM, Slatten K, Paulsen BS, O’Neill M, van Halbeek H. 1991. Structural analysis of the glycoprotein allergen Art v II from the pollen of mugwort (Artemisia vulgaris L.). Journal of Biological Chemistry 255:2660-2668.

Paschke A, Kinder H, Zunker K, Wigotzki M, Webbecher R, Vieluf D, Steinhart H. 2001. Characterization of allergens in mango fruit and ripening dependence of the allergenic potency. Food and Agricultural Immunology 13:51-61.

Pastorello EA, Conti A, Pravettoni V, Farioli L, Rivolta F, Ansaloni R, Ispano M, Incorvaia C, Giuffrida M. 1998. Identification of actinidin as the major allergen of kiwi fruit. Journal of Allergy and Clinical Immunology 101:531-537.

Pastorello EA, Pravettoni V, Ispano M, Farioli L, Ansaloni R, Rotondo F, Incorvaia C, Asman I, Bengtsson A, Ortolani C. 1996. Identification of the allergenic components of kiwi fruit and evaluation of their cross-reactivity with timothy and birch pollens. Journal of Allergy and Clinical Immunology 98:601-610.

Rudescho O, Fahlbusch B, Steurich F, Schlenvoigt G, Jager L. 1998. Kiwi allergens and their crossreactivity with birch, rye, timothy and mugwort pollen. Journal of Investigational Allergology and Clinical Immunology 8:78-84.

Sampson H. 1999. Food allergy. Part 1: Immunopathogenesis and clinical disorders. Journal of Allergy and Clinical Immunology 103:717-728.

Towbin H, Staehelin T, Gordon J. 1979. Electrophoretic transfer of proteins from polyacrylamide gels to nitrocellulose sheets: Procedure and some applications. Proceedings of the National Academy of Sciences $76: 4350-4354$. 


\section{M. Gavrovic-fankulovic et al.}

Varughese KI, Su Y, Cromwell D, Hasnain S, Xuong N. 1992. Crystal structure of an actinidin-E-64 complex. Biochemistry 31:5172-5176.

Vieths S, Jankiewicz A, Schoning B, Aulepp H. 1994. Apple allergy: The IgE-binding potency of apple strains is related to the occurrence of the $18 \mathrm{kDa}$ allergens. Allergy 49:262-271.

Vieths S, Scheurer S, Reindl J, Luttkopf D, Wangorsch A, Kastner M, Haase T, Haustein D. 2001. Optimized allergen extracts and recombinant allergens in diagnostic applications. Allergy 56(Suppl. 67):78-82.

Wang $\mathrm{H}, \mathrm{Ng}$ TB. 2002. Isolation of an antifungal thaumatin-like protein from kiwi fruit. Phytochemistry $61: 1-7$.

Yagami T, Haishima Y, Nakamura A, Osuna H, Ikezawa Z. 2000. Digestibility of allergens extracted from natural rubber latex and vegetable foods. Journal of Allergy and Clinical Immunology 106:752-762.

Yunginger JM. 1991. Standardization of allergenic extracts. Annals of Allergy 66:107-112. 